\title{
PENYELESAIAN KREDIT BERMASALAH PADA PT. BANK PERKREDITAN RAKYAT (BPR) NAGARI KASANG
}

\author{
Utari Herman, Ratna Widayati \\ Akademi Keuangan dan Perbankan Padang \\ ratnawidayati@akbpstie.ac.id
}

\begin{abstract}
ABSTRAK
Tujuan Penelitian ini adalah untuk mengetahui apa penyebab dari terjadinya kredit bermasalah dan untuk mengetahui cara penyelesaian kredit bermasalah di PT. BPR Nagari Kasang. Metode analisa data untuk penelitian ini adalah metode deskriptif yaitu dengan menguraikan data secara sistematis dari fakta-fakta yang didapat kemudian dihubungkan dengan prosedur penyelesaian kredit bermasalah pada PT. Bank Perkreditan Rakyat (BPR) Nagari Kasang. Hasil Penelitian 1) Terjadinya kredit bermasalah di PT. BPR Nagari Kasang disebabkan oleh faktor intern yaitu pejabat kredit mudah dipengaruhi atau dipaksa oleh calon nasabah, kurangnya pemahaman terhadap kebutuhan keuangan yang sebenarnya dari calon nasabah dan manfaat kredit yang diberikan seperti kredit modal kerja digunakan untuk komsumtif, kurangnya pengecekan latar belakang calon nasabah. Dan juga disebabkan oleh faktor ektern yaitu karena merosotnya perekonomian debitur, terjadinya PHK mendadak di tempat kerja debitur, penurunan onset usaha debitur, dan terjadnya konflik keluarga. 2) Upaya penyelesaian kredit bermasalah yang disebabkan oleh faktor intern dilakukan dengan peringatan tertulis dalam bentuk Surat Peringatan (SP), mutasi, dan penurunan jabatan, serta upaya penyelesaian kredit bermasalah yang disebabkan oleh faktor ekstern dilakukan dengan mengirim Surat Peringatan SP 1 sampai SP 3 melakukan penagihan kepada pihak yang ikut serta menandatangani perjanjian kredit, dan terakhir melakukan penarikan dan pelelangan agunan.
\end{abstract}

Kata Kunci: Kredit Bermasalah, BPR

\section{PENDAHULUAN}

Perbankan di Indonesia merupakan sasaran pembangunan ekonomi, dimana perbankan diharapkan mampu mengembangkan dan menunjukkan perekonomian yang lebih maju, khususnya dalam meningkatkan kesejahteraan rakyat banyak. Perbankan memberikan kesempatan kepada masyarakat untuk berpartisipasi dalam membangun dengan mengadakan pengumpulan dana melalui usaha-usaha yang dijalankan perbankan, seperti tabungan, deposito, giro maupun kredit. Adanya tabungan, deposito maupun kredit menimbulkan terjadinya perputaran uang di masyarakat sehingga dapat dipergunakan untuk pembangunan.

PT. BPR Nagari Kasang adalah salah satu perbankan yang bergerak dalam bidang usaha menghimpun dana masyarakat berupa tabungan, deposito dan menyalurkannya dana tersebut kepada masyarakat dalam bentuk kredit. 
Penyaluran kredit mengandung resiko, karena adanya keterbatasan kemampuan manusia dalam memprediksi masa yang akan datang, untuk itu bank harus berusaha untuk menekan resiko munculnya kredit bermasalah. Pihak bank juga perlu menilai kelayakan usaha dari debitur dan juga diperlukan adanya pengelolaan dan pengawasan, sehingga kesinambungan usaha perbankan tetap terjaga.

Kemungkinan resiko yang timbul dalam penyaluran kredit adalah terjadi transaksi pembayaran kembali yang atas kredit dalam kondisi tidak terbayar atau pembayaran kembali dari debitur tersendat, dengan kata lain ada suatu indikasi terjadi kredit bermasalah. Kondisi ini akan menimbulkan kinerja likuiditas BPR terganggu dan berakibat buruk sehingga akan menjadikan BPR tersebut beku operasi, oleh sebab itu dibutuhkan suatu pengawasan pada kegiatan kredit tersebut oleh pihak menejemen, dari awal proses kegiatan hingga penyelesaian kegiatan kredit tersebut. Berdasarkan uraian diatas maka penulis tertarik untuk membahasnya dalam Penelitian yang berjudul Penyelesaian Kredit Bermasalah Pada PT. Bank Perkreditan Rakyat Nagari Kasang.

Perumusan Masalah

1. Apa yang menyebabkan terjadinya kredit bermasalah pada PT. BPR Nagari Kasang?

2. Bagaimana cara penyelesaian kredit bermasalah pada PT. BPR Nagari Kasang?

Tujuan Penelitian

Adalah untuk mengetahui apa penyebab dari terjadinya kredit bermasalah dan untuk mengetahui cara penyelesaian kredit bermasalah di PT. BPR Nagari Kasang.

Manfaat Penelitian

Manfaat yang diharapkan dari penelitian ini adalah:

1. Bagi penulis, dapat memperluas wawasan dan menambah ilmu pengetahuan penulis mengenai prosedur penyelesaian kredit bermasalah terutama dalam konteks perbandingan antara teori dengan praktek.

2. Bagi PT. Bank Perkreditan Rakyat (BPR) Nagari Kasang hasil penelitian ini diharapkan dapat memberikan masukan dan dapat dijadikan sebagai bahan pertimbangan dalam melakukan penyelesaian kredit bermasalah.

3. Bagi pembaca, hasil penelitian ini dapat menjadi bahan sumbangan pemikiran dan sebagai bahan bagi mahasiswa yang berminat untuk mengkaji prosedur penyelesaian kredit bermasalah pada PT. Bank Perkreditan Rakyat (BPR).

\section{METODE PENELITIAN}

Dalam pengumpulan data dan bahan untuk penelitian ini digunakan metode penelitian sebagai berikut :

\section{Metode Pengumpulan Data}

1. Penelitian kepustakaan

Penelitian kepustakaan yaitu mencari landasan terori dengan mempelajari buku-buku bacaan, bahan bahan kuliah serta artikel-artikel yang berhubungan dengan topik pembahasan.

2. Penelitian Lapangan

Penelitian lapangan yaitu dengan melakukan penelitian langsung ke PT. BPR Nagari Kasang dengan melakukan wawancara dan tanya jawab guna 
mendapatkan data-data dan keterangan-keterangan yang erat kaitanya dengan penulisan ini.

\section{Metode Analisa Data}

Metode analisa data untuk menulis tugas akhir ini adalah metode deskriptif yaitu dengan menguraikan data secara sistematis dari fakta-fakta yang didapat kemudian dihubungkan dengan prosedur penyelesaian kredit bermasalah pada PT. Bank Perkreditan Rakyat (BPR) Nagari Kasang.

\section{HASIL PENELITIAN DAN PEMBAHASAN \\ Landasan Teori \\ Pengertian Kredit}

Dalam Undang - undang Perbankan No 10 tahun 1998 yang merupakan perubahan atas Undang - undang No. 7 tahun 1992 "kredit" adalah penyediaan uang atau tagihan yang dapat dipersamakan dengan itu, berdasarkan persetujuan atau kesepakatan pinjam meminjam antara bank dengan pihak lainnya yang mewajibkan pihak peminjam melunasi hutangnya dalam jangka waktu tertentu dengan pemberian bunga.

Pengertian Kredit menurut Irfan fahmi (2014:2) Kredit berasal dari bahasa latin yaitu "credere" yang artinya kepercayaan. Kredit dan kepercayaan (trust) ibarat sekeping mata logam yang tidak dapat dipisahkan. Karena tidak akan mungkin adanya pemberian pinjaman tanpa adanya kepercayaan, dan kepercayaan itu sangat mahal harganya.

Menurut Kasmir (2016:274) secara umum kredit dikatakan kepercayaan. Dalam bahasa latin disebut "credere" artinya kepercayaan pihak bank (kreditur) kepada nasabah (debitur), bank percaya nasabah pasti akan mengembalikan pinjamannya sesuai kesepakatan yang telah dibuat. Dapat diartikan pula bahwa debitur memperoleh kepercayaan dari bank untuk memperoleh dana dan menggunakan dana tersebut sebagaimana mestinya serta mampu untuk mengembalikan sesuai dengan perjanjian yang telah disepakati kedua belah pihak.

\section{Jenis - jenis Kredit}

Menurut Kasmir (2016:274) secara umum kredit dibagi dalam 5 kelompok yaitu :

1. Dilihat dari segi agunan

a. Kredit investasi

Kredit yang diberikan untuk investasi, misalnya membangun pabrik, rumah, pemberian mesin-mesin, tanah dan lainnya. Kredit investasi biasanya digunakan untuk jangka waktu panjang.

b. Kredit modal kerja

Kredit yang diberikan untuk keperluan modal kerja, misalnya untuk membeli bahan baku, pembayaran gaji, dan biaya lainnya. Kredit modal kerja diberikan dalam waktu yang relatif pendek dan satu kali siklus operasi.

2. Dilihat dari segi tujuan

a. Kredit Produktif

Kredit yang diberikan untuk menghasilkan sesuatu (proses produksi), baik barang maupun jasa, misalnya kredit diberikan untuk industri (pabrik), pertanian, peternakan, perhotelan, dan lainnya. 


\section{b. Kredit Konsumtif}

Kredit yang diberikan untuk digunakan secara pribadi atau dipakai (dikosumsi) sendiri, misalnya membeli rumah atau kendaraan yang akan digunakan untuk keperluan pribadi.

c. Kredit Perdagangan

Kredit yang diberikan kepada para pedagang, biasanya digunakan untuk membeli barang dagangan yang pembayarannya diharapkan dari hasil penjualan barang dagangannya sendiri.

3. Dilihat dari jangka waktu

a. Kredit jangka pendek

Merupakan kredit yang memiliki jangka waktu maksimal satu tahun atau kurang dari satu tahun, biasnya untuk modal kerja. Contohnya untuk pertanian menanam padi.

b. Kredit jangka menengah

Merupakan kredit yang memiliki jangka waktu satu sampai tiga tahun, biasanya untuk investasi. Sebagai contoh kredit untuk pertanian seperti jeruk, atau peternakan kambing.

c. Kredit jangka panjang

Merupakan kredit yang memiliki jangka waktu lebih dari satu atau tiga tahun, biasanya kredit ini untuk investasi jangka panjang seperti perkebunan karet, kelapa sawit atau manufaktur untuk kredit konsumtif seperti perumahan.

4. Dilihat dari segi jaminan

a. Kredit jaminan

Kredit yang diberikan dengan satu jaminan, jaminan tersebut dapat berupa barang atau tidak berwujud atau jaminan orang, artinya setiap kredit yang yang dikeluarkan akan dilindungi senilai jaminan yang diberikan calon debitur.

b. Kredit tanpa jaminan

Merupakan kredit yang diberikan tanpa jaminan barang, namun sebenarnya meskipun tidak ada jaminan, dalam praktiknya ada jaminan kemampuan membayar dari nasabah, misalnya pegawai tetap yang menghasilkan penghasilan tetap.

5. Dilihat dari sektor usaha

a. Kredit sektor pertanian, merupakan kredit yang dibiayai untuk sektor perkebunan dan pertanian rakyat. Sektor usaha pertanian dapat berupa jangka pendek atau jangka panjang.

b. Kredit sektor industri menirupakan kredit yang diberikan kepada industri, baik industri kecil, menengah maupun besar.

c. Kredit sektor profesi, merupakan kedit yang diberikan kepada yang profesional seoerti dokter, pengacara, dosen, dan lainnya.

\section{Prosedur Dalam Pemberian Kredit}

Pada dasarnya proses pemberian kredit disemua bank tidak jauh berbeda, yang menjadi perbedaan terletak dari bagaiman cara-cara bank tersebut menilainya serta persyaratan yang telah ditetapkan oleh masingmasing bank.

Proses pemberian kredit pada Bank dilaksanakan seperti dengan alur proses sebagai berikut : 


\section{Gambar 1}

Proses Pemberian Kredit Pada Bank

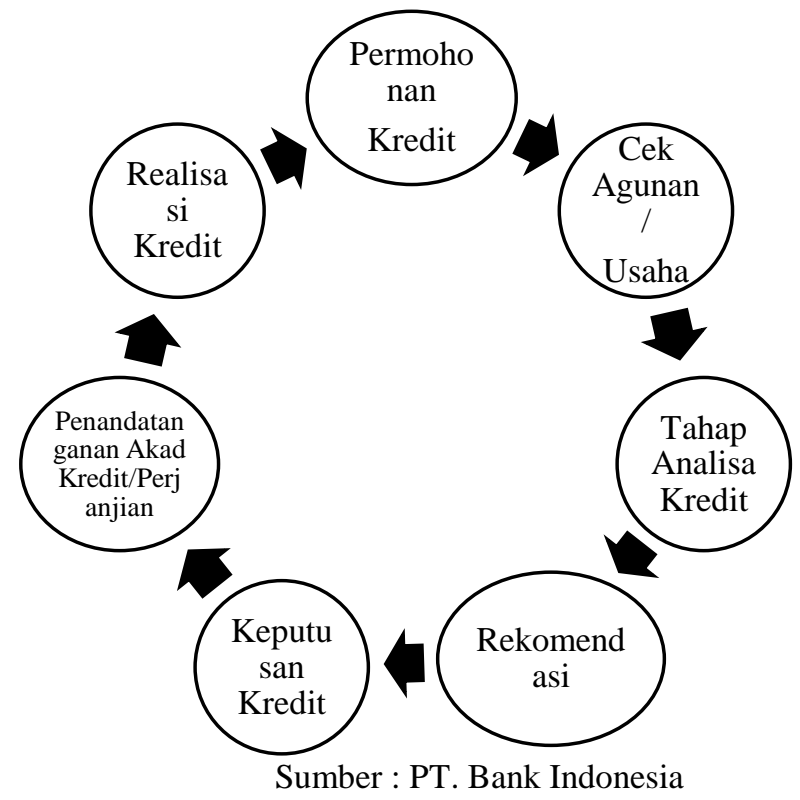

1. Permohonan Kredit

Dalam hal ini Debitur mengajukan permohonan kredit secara tertulis dengan melengkapi dokumen yang disyaratkan bank yaitu:

a. Fotocopy KTP dan Kartu Keluarga

b. Pas foto

c. Fotocopy Akta pendirian berikut seluruh perubahannya

d. Fotocopy perizinan usaha:

1) NPWP

2) SIUP

3) TDP

4) SITU

e. Fotocopy dokumen jaminan (sertifikat tanah, BPKB, Surat Toko, lainnya)

f. Data-data keuangan (Neraca Dan Laporan laba rugi)

g. Dokumen pendukung lainnya

Dalam mengidentifikasikan permohonan kredit yang diajukan, Bank memiliki kriteria calon debitur sebagai berikut:

a. Warga Indonesia (berusia minimal 21 tahun atau telah menikah dan berakal sehat).

b. Mempunyai penghasilan yang jelas, tetap dan diyakini oleh pihak Bank.

c. Tidak tercatat daftar hitam (black list)

\section{Cek Agunan/Usaha}

Setelah pihak bank memeriksa kelengkapan dokumen tersebut, pihak bank melanjutkan proses pemberian kredit dengan melakukan cek agunan atau usaha debitur, tujuannya untuk mengetahui modal calon debitur. Setelah semuanya lancar pihak bank akan melakukan penilaian terhadap agunan yang dijamin oleh calon debitur, misalnya SK karyawan atau surat-surat tanah atau sertifikat rumah. 


\section{Tahap Analisa Kredit}

Pada tahap analisa kredit, pekerjaan yang dilakukan meliputi:

a. Mempersiapkan pekerjaan-pekerjaan penguraian dari segala aspek, baik keuangan maupun non keuangan untuk mengetahui kemungkinan dapat atau tidaknya dipertimbangkan suatu permohonan kredit.

b. Menyusun laporan analisa yang diperlukan, yang berisi penguraian dan kesimpulan serta penyajian alternatif-alternatif sebagai bahan pertimbangan untuk pengambilan keputusan terhadap permohonan kredit.

\section{Rekomendasi}

Apabila hasil dari analisa kredit yang dilakukan oleh defisi kredit sesuai dengan ketentuan Bank maka defisi kredit akan mengajukan kepada pimpinan untuk merekomendasikan kredit tersebut.

\section{Keputusan Kredit}

Dari hasil rekomendasi kredit tersebut, pihak bank memberikan keputusan apakah permohonan diterima atau ditolak.

\section{Penandatanganan Akad Kredit/Perjanjian}

Setelah kredit diterima, maka kedua belah pihak melakukan perjanjian kredit dengan menanda tangani akad kredit, dan pihak bank akan mengikat agunan yang diajaminkan.

\section{Realisasi Kredit}

Setelah itu kredit akan direalisasikan dengan persyaratan dengan membuka rekening tabungan di Bank. Setelah semuanya selesai kredit akan dicairkan dan bisa diambil oleh pihak debitur atas realisasi pemberian kredit.

\section{Pengertian Kredit Bermasalah}

Pengertian kredit bermasalah menurut Kuncoro dan Suhardjono (2002:462) adalah suatu keadaan dimana nasabah sudah tidak sanggup membayar sebagian atau seluruh kewajiban kreditnya.

Menurut Rivai (2006:476) ada beberapa pengertian kredit bermasalah:

1. Kredit yang didalam pelaksanaannya belum mencapai / memenuhi target yang diinginkan oleh pihak bank.

2. Kredit yang memiliki timbulnya resiko dikemudian hari bagi bank dalam arti luas.

3. Mengalami kesulitan didalam penyelesaian kewajiban-kewajibannya, baik dalam bentuk pembayaran kembali pokoknya dan atau pembayaran bunga, denda keterlambatan serta ongkos-ongkos bank yang menjadi beban nasabah yang bersangkutan.

4. Kredit dimana pembayaran kembalinya dalam bahaya, terutaa apabila sumber-sumber pembayaran kembali diharapkan diperkirakan tidak cukup untuk membayar kembali kredit, sehingga belum mencapai / memenuhi target yang diinginkan.

5. Kredit dimana terjadi cidera janji dalam pembayaran kembali sesuai dengan perjanjian, sehingga terdapat tunggakan, atau ada potensi kerugian diperusahaan nasabah sehingga memiliki kemungkinan timbulnya resiko dikemudian hari bagi bank.

6. Kredit golongan perhatian khusus, kurang lancar, diragukan dan macet serta golongan lancar yang berpotensi menunggak.

Kredit bermasalah Menurut sutojo (2008:13) yaitu : 
1. Terjadi keterlambatan pembayaran bunga dan /atau kredit induk lebih dari 90 hari sejak tanggal jatuh temponya.

2. Tidak dilunasi sama sekali.

3. Diperlukan negosiasi kembali atas syarat pembayaran kembali kredit dan bunga yang tercantum dalam perjanjian kredit.

\section{Kolektibilitas Kredit}

Ketentuan Bank Indonesia No. 31/147/KEP/DIR tanggal 12 November 1988, untuk melihat aktiva produktif bank dan seberapa jauh kredit bermasalah terdapat pada bank tersebut dinilai berdasarkan kolektibilitas kreditnya. Kolektibilitas kredit adalah keadaan pembayaran pokok, angsuran pokok, dan bunga kredit oleh nasabah serta tingkat kemungkinan diterimanya kembali dana yang dinamkan dalam surat-surat berharga atau penanaman lainnya. Dengan melihat kolektibilitas kredit dapat dinilai kualitas kredit yang diberikan.

Kolektibilitas kredit berdasarkan ketentuan Bank Indonesia sebagai berikut :

1. Kredit lancar

Kredit lancar adalah kredit yang tidak mengalami penundaan pengembalian pokok pinjaman dan pembayaran bunga.

2. Kredit dalam perhatian khusus

Kredit dalam perhatian khusus adalah kredit yang mempunyai tunggakan pokok atau bunga telah mengalami penundaan selama $1 \mathrm{~s} / \mathrm{d} 90$ hari.

3. Kredit kurang lancar

Kredit kurang lancar adalah kredit yang pengembalian pokok pinjaman dan pembayaran bunganya telah mengalami penundaan selama $91 \mathrm{~s} / \mathrm{d} 180$ hari dari jangka waktu yang diperjanjikan.

4. Kredit diragukan

Kredit diragukan adalah kredit pengembalian pokok pinjaman dan pembayaran bunganya telah mengalami penundaan selama $181 \mathrm{~s} / \mathrm{d} 270$ hari atau dua kali jadwal yang telah diperjanjikan.

5. Kredit macet

Kredit macet adalah kredit yang pengembalian pokok pinjaman dan pembayaran bungannya telah mengalami penundaan lebih dari satu tahun sejak jatuh tempo menurut jadwal yang telah diperjanjikan.

\section{Sebab-Sebab Terjadinya Kredit Bermasalah}

Menurut Kuncoro dan Suhardjono (2011:427), secara umum dalam pemberian kredit banyak menghadapi berbagai hambatan, yang terdiri dari hambatan intern dan ekstern yang mengakibatkan kredit bermasalah. sebagai berikut :

Hambatan intern merupakan hambatan yang timbul dari pihak bank

1. Kurangnya pengecekan latar belakang calon nasabah.

2. Kurang tajam dalam menganalisis terhadap maksud dan tujuan pengguanaan kredit dan sumber pembayaran kembali.

3. Kurang pemahaman terhadap kebutuhan keuangan yang sebenarnya dari calon nasabah dan manfaat kredit yang diberikan.

4. Kurang mahir dalam mengalisis laporan keuangan calon nasabah.

5. Kurang lengkap mencantumkan syarat - syarat.

6. Pemberian kelonggaran terlalu banyak.

7. Pejabat kredit mudah dipengaruhi, intimidasi atau dipaksa oleh calon nasabah. 
Hambatan ektern merupakan hambatan yang timbul dari pihak nasabah yaitu :

1. Merosotnya perekonomian debitur

2. Terjadinya PHK mendadak di tempat kerja debitur

3. Penurunan onset usaha debitur

4. Usaha debitur mengalami kebangkrutan

5. Terjadinya konflik keluarga ( Bercerai )

\section{Tahapan - Tahapan Penyelesaian kredit}

Menurut Kasmir (2012:149), tahapan-tahapan dalam penyelesaian kredit, terdiri dari :

1. Tahapan Pemantauan

Bank melakukan pemantauan secara intensif dan disiplin terhadap portofolio kredit secara keseluruhan untuk mengantisipasi resiko kerugian dengan melakukan hal-hal sebagai berikut :

a. Meneliti Kualitas Kredit.

b. Melibatkan Audit Intern dalam pengawasan pemberian kredit.

c. Menetapkan dan menentukan debitur-debitur yang kualitas kreditnya berubah dan lancar menjadi dalam perhatian khusus, kurang lancar, diragukan dan atau macet.

2. Tahapan Pengawasan

Bank melakukan analisa permasalahan dan evaluasi secara berkala untuk memperbaiki kualitas kredit dengan melakukan hal-hal sebagai berikut:

a. Menetapkan dan menentukan unit kerja pengelola kredit sebagai berikut :

1) Klarifikasi kredit dengan kualitas lancar dan dalam perhatian khusus dikelola oleh satuan kerja perkreditan Cabang (SKPC).

2) Klarifikasi kredit bermasalah yaitu : kredit dengan kualitas kurang lancar, Diragukan dan macet serta kredit ekstrakomtabel dikelola oleh satuan kerja perkreditan khusus (SKPK) Cabang dibantu oleh satuan kerja Perkreditan Khusus ( SKPK) kantor pusat.

b. Membuat analisa permasalahan dan penyelesaian setiap terjadi perubahan kualitas kredit Debitur, kelompok Debitur dan Debitur ini dari Kualitas Lancar menjadi dalam perhatian khusus, kurang lancar, diragukan dan aturan sebagai berikut :

1) Analisa permasalahan dan rencana tindakan penyelesaian

2) kredit bermasalah terhadap debitur-debitur dengan kualitas kredit dalam perhatian khusus dilakukan setiap 1 (Satu) bulan sekali.

3) Analisa permasalahan dan rencana tindakan penyelesaian kredit bermasalah terhadap debitur-debitur dengan kualitas kredit Kurang Lancar dan Diragukan serta Macet dibuat secara triwulan

c. Analisa masalah minimal menginformasikan hal-hal sebagai berikut:

1) Riwayat hubungan Debitur, kelompok Debitur dan Debitur dan Debitur inti dengan Bank.

2) Alasan dan penyebab terjadinya tunggakan kredit.

3) Analisa penyelesaian kredit bermasalah.

d. Penetapan strategi minimal menginformasikan hal-hal sebagai berikut :

1) Perkiraan hasil yang diharapkan

2) Sasaran penyelesaian kredit bermasalah

3) Strategi penyelesaian 
4) Strategi alternatif

5) Rencana tindakan

\section{ANALISA DAN PEMBAHASAN}

\section{Aktifitas Pemberian Kredit PT. BPR Nagari Kasang}

Pemberian kredit pada Bank Perkreditan Rakyat Nagari Kasang dilaksanakan dengan alur proses sebagai berikut :

Gambar 2

Proses Pemberian Kredit Pada PT. Bank Perkreditan Rakyat Nagari Kasang
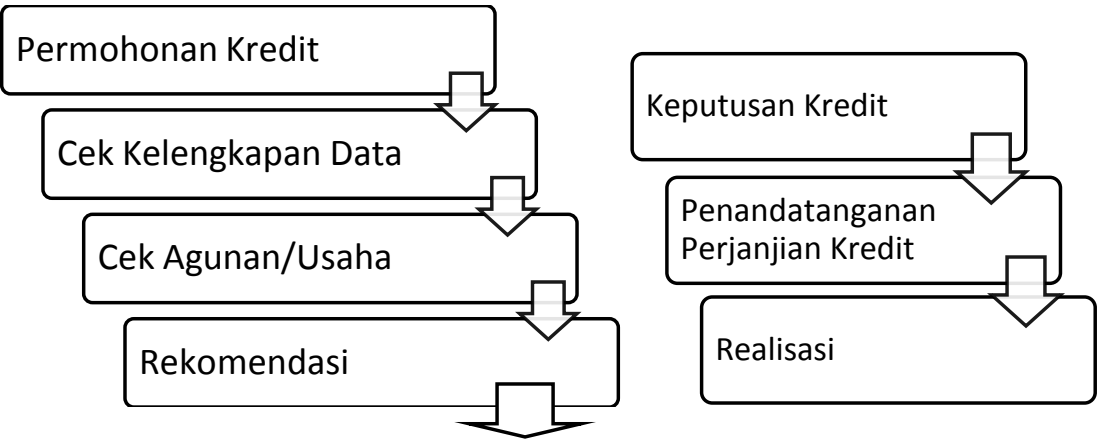

Sumber : PT. Bank Perkreditan Rakyat

1. Permohonan Kredit

Pada tahap ini, permohonan kredit harus dilengkapi dengan persyaratan sebagai berikut :

a. Warga Indonesia (berusia minimal 21 tahun atau telah menikah dan berakal sehat).

b. Mempunyai penghasilan yang jelas, tetap dan diyakini oleh pihak BPR Nagari Kasang.

c. Tidak tercatat daftar hitam (black list)

2. Cek Kelangkapan Data

Setelah debitur melakukan permohonan kredit, maka debitur harus melengkapi data-data sebagai berikut:

a. Fotocopy KTP dan Kartu Keluarga

b. Pas foto

c. Fotocopy Akta pendirian berikut seluruh perubahannya

d. Fotocopy perizinan usaha:

1) NPWP

2) SIUP

3) TDP

4) SITU

e. Fotocopy dokumen jaminan (sertifikat tanah, BPKB, Surat Toko, lainnya)

f. Data-data keuangan (Neraca Dan Laporan laba rugi)

g. Dokumen pendukung lainnya

3. Cek Anggunan / Usaha

Setelah memeriksa kelangkapan dokumen pihak BPR Nagari Kasang melanjutkan proses cek agunan usaha debitur, tujuannya untuk mengetahui modal calon debitur.

4. Rekomendasi 
Apabila hasil dari analisa kredit telah memenuhi syarat, maka tim dari difisi kredit BPR Nagari Kasang akan mengajukan kepada pimpinan untuk disetujui kredit tersebut.

5. Keputusan kredit

Dari hasil rekomendasi kredit tersebut, pihak BPR Nagari Kasang memberikan keputusan apakah permohonan diterima atau ditolak.

6. Penanda Tanganan Pemberian Kredit

Setelah kredit diterima, maka kedua belah pihak melakukan perjanjian kredit dengan menanda tangani akad kredit, dan pihak bank akan mengikat agunan yang dijaminkan.

7. Realisasi Kredit

Setelah itu akan direalisasikan dengan persyaratan membuka rekening tabungan di Bank Perkreditan Rakyat Nagari Kasang, setelah semuanya selesai kredit akan dicairkan dan bisa diambil oleh pihak debitur atas realisasi pemberian kredit.

PT. BPR Nagari Kasang memiliki 2 jenis kredit yaitu kredit modal kerja, dan kredit konsumtif. Berikut ini disajikan data kredit konsumtif dan modal kerja PT. BPR Nagari Kasang periode 2014-2016.

Tabel 1

Data Kredit Pada Bank Perkreditan Rakyat Nagari Kasang 2014-2016 (Dalam Jutaan Rupiah)

\begin{tabular}{|c|c|c|c|}
\hline \multirow{2}{*}{ Tahun } & \multicolumn{2}{|c|}{ Jenis Kredit } & \multirow{2}{*}{ Total } \\
\cline { 2 - 3 } & Modal Kerja & Konsumtif & \\
\hline 2014 & 395.817 & 180.813 & 576.630 \\
\hline 2015 & 451.679 & 197.823 & 649.502 \\
\hline 2016 & 646.534 & 209.545 & 856.079 \\
\hline
\end{tabular}

Sumber : Data Mentah PT. BPR Nagari Kasang

Dari tabel diatas dapat diuraikan bahwa kredit BPR

Nagari Kasang pada tahun 2014 total kredit nya sebesar Rp 576.630.000, dengan keterangan kredit Modal Kerja sebesar Rp 395.817.000, dan Kredit Konsumtif sebesar Rp 180.813.000, Sedangkan pada tahun 2015 total kredit nya sebesar Rp 649.502.000, dengan keterangan kredit Modal Kerja sebesar Rp 451.679.000, dan kredit Konsumtif sebesar Rp 197.823.000, dan pada tahun 2016 total kredit nya sebesar Rp 856.079.000, dengan keterangan kredit Modal Kerja sebesar Rp 646.534.000, dan kredit Konsumtif sebesar Rp 209.545.000, Dari data diatas dapat disimpulkan bahwa tingkat kredit BPR Nagari Kasang setiap tahunnya meningkat.

\section{Kredit Bermasalah Pada PT. BPR Nagari Kasang}

Untuk melihat kredit produktif dan seberapa jauh kredit bermasalah pada PT. Bank Perkreditan Rakyat Nagari Kasang dinilai berdasarkan kolektibilitas kreditnya.

Kolektibilitas kredit PT. BPR Nagari Kasang tahun 2014-2016 dapat dilihat pada tabel dibawah ini : 
Tabel 2

Kolektibilitas Kredit PT. Bank Perkreditan Rakyat Nagari Kasang (Dalam Jutaan Rupiah)

\begin{tabular}{|c|l|c|c|c|c|c|c|}
\hline No & $\begin{array}{l}\text { Jenis } \\
\text { Kredit }\end{array}$ & $\mathbf{2 0 1 4}$ & $\mathbf{\%}$ & $\mathbf{2 0 1 5}$ & $\mathbf{\%}$ & $\mathbf{2 0 1 6}$ & $\mathbf{\%}$ \\
\hline 1 & Lancar & 514.407 & 89,20 & 607.490 & 93,53 & 817.655 & 95,51 \\
\hline 2 & $\begin{array}{l}\text { Kurang } \\
\text { lancar }\end{array}$ & 26.355 & 4,57 & 16.929 & 2,60 & 20.543 & 2,39 \\
\hline 3 & Diragukan & 28.354 & 4,91 & 17.894 & 2,75 & 11.231 & 1,31 \\
\hline 4 & Macet & 7.514 & 1,30 & 7.189 & 1,10 & 6.650 & 0,77 \\
\hline & Jumlah & 576.630 & 100 & 649.502 & 100 & 856.079 & 100 \\
\hline & NPL & & 10,79 & & 6,47 & & 4,47 \\
\hline
\end{tabular}

Sumber : Data olahan PT. BPR Nagari Kasang

Dari tabel 3.2 diatas dapat dilihat bahwa tingkat kolektibilitas nasabah cenderung berfluktuasi. Pada tahun 2014 tingkatan NPL yaitu sebesar 10,79\% dengan kredit lancar nya sebesar 89,20\%, kredit kurang lancar sebesar 4,57\%, kredit diragukan sebesar 4,91\% dan kredit macet sebesar 1,30\% yang artinya pada tahun 2014 ini terjadi tingginya tingkat NPL yang cukup signifikan, pada tahun 2015 dan 2016 terjadi penurunan kredit bermasalah.

Dengan demikian dapat diambil kesimpulan bahwa pada dasarnya kredit yang disalurkan oleh PT. BPR Nagari Kasang cenderung lancar. Walaupun terjadi kredit bermasalah dari tahun 2014-2016 namun cenderung menurun yang disebabkan pihak PT. Perkreditan Rakyat Nagari Kasang lebih teliti dalam memberikan kreditnya agar tidak timbulnya kredit bermasalah.

\section{Faktor-Faktor Yang Menyebabkan Terjadinya Kredit Bermasalah Pada PT. BPR Nagari Kasang}

a. Faktor intern

Di PT. BPR Nagari Kasang hal ini terjadi karena pejabat kredit mudah dipengaruhi atau dipaksa oleh calon nasabah, kurangnya pemahaman terhadap kebutuhan keuangan yang sebenarnya dari calon nasabah dan manfaat kredit yang diberikan, dan kurangnya pengecekan latar belakang calon nasabah.

b. Faktor ekstern

Hal ini terjadi disebabkan karena merosotnya perekonomian debitur, terjadinya PHK mendadak di tempat kerja debitur, penurunan onset usaha debitur, dan terjadnya konflik keluarga.

\section{Penyelesaian Kredit Bermasalah}

Bank PT. BPR Nagari Kasang dalam menyelesaikan kredit bermasalahnya melihat tingkat kesulitan yang dihadapi nasabah. Tidak semua kredit bermasalah dapat ditangani dengan cara yang sama, beberapa diantaranya mungkin dengan cukup adanya koreksi disertai dengan monitoring yang lebih ketat, sementara yang lain harus ditempuh dengan cara penyehatan kredit.

Langkah-langkah yang dilakukan PT. BPR Nagari Kasang untuk menyelesaikan kredit bermasalahnya yang disebabkan oleh faktor intern :

a. Peringatan Tertulis

Dengan memberikan surat peringatan (SP) kepada karyawan yang nasabahnya mengalami kredit bermasalah agar kreditnya dapat dilunasi. 
b. Mutasi

Memindah tugaskan karyawan yang bermasalah ke daerah yang terpencil agar karyawan tersebut bisa meningkatkan kinerjanya menjadi lebih baik lagi.

c. Penurunan Jabatan (demosi)

Menurunkan jabatan karyawan kredit ke bidang yang lain dikarenakan karyawan tersebut tidak bisa dipercaya lagi di bidang kredit oleh sebab itu karyawan kredit akan dipindah tugaskan ke divisi lain, berupa kedivisi kabid dana atau kedivisi staaf umum.

Langkah-langkah yang dilakukan PT. BPR Nagari Kasang untuk menyelesaian kredit bermasalahnya yang disebabkan oleh faktor ekstern :

a. Melakukan peringatan

Bank PT. BPR Nagari Kasang mengirimkan surat peringatan (SP 1) sampai (SP 3) kepada debitur untuk segera membayar tunggakan kredit yang telah terjadi.

b. Penagihan

PT. BPR Nagari Kasang melakukan Penagihan kepada debitur, apabila debitur tidak sanggup membayar tunggakan kreditnya, maka pihak PT. BPR Nagari Kasang akan menghubungi pihak penanggung jawab yang ikut serta menandatangani perjanjian kredit.

c. Restrukturisasi kredit

PT. BPR Nagari Kasang memberikan solusi kepada debitur untuk menyelesaikan kredit bermasalahnya dengan cara memperpanjang jangka waktu kreditnya, dan melakukan penambahan modal usaha debitur.

d. Penarikan

Apabila nasabah tidak sanggup lagi membayar tunggakan kreditnya maka PT. BPR Nagari Kasang akan melakukan penarikan agunan debitur.

e. Pelelangan

Setelah melakukan penarikan maka PT. BPR Nagari Kasang melakukan pelelangan agunan untuk melunasi tunggakan kredit debitur.

\section{PENUTUP}

\section{Kesimpulan} berikut :

Berdasarkan uraian diatas, maka dapat ditarik kesimpulan sebagai

1. Terjadinya kredit bermasalah di PT. BPR Nagari Kasang disebabkan oleh faktor intern yaitu pejabat kredit mudah dipengaruhi atau dipaksa oleh calon nasabah, kurangnya pemahaman terhadap kebutuhan keuangan yang sebenarnya dari calon nasabah dan manfaat kredit yang diberikan seperti kredit modal kerja digunakan untuk komsumtif, kurangnya pengecekan latar belakang calon nasabah. Dan juga disebabkan oleh faktor ektern yaitu karena merosotnya perekonomian debitur, terjadinya PHK mendadak di tempat kerja debitur, penurunan onset usaha debitur, dan terjadnya konflik keluarga.

2. Upaya penyelesaian kredit bermasalah yang disebabkan oleh faktor intern dilakukan dengan peringatan tertulis dalam bentuk Surat Peringatan (SP), mutasi, dan penurunan jabatan, serta upaya penyelesaian kredit bermasalah yang disebabkan oleh faktor ekstern dilakukan dengan mengirim Surat Peringatan SP 1 sampai SP 3 melakukan penagihan 
kepada pihak yang ikut serta menandatangani perjanjian kredit, dan terakhir melakukan penarikan dan pelelangan agunan.

\section{Saran}

Setelah memperhatikan masalah yang dihadapi oleh PT. BPR Nagari Kasang maka penulis memberikan saran-saran Untuk mengantisipasi kredit bermasalah sebaiknya bank meningkatkan monitoring dan pengawasan terhadap kredit yang diberikan baik mengenai manajemen maupun keadaan debitur, sebelum kredit diberikan pihak bank memperhatikan kriteria calon nasabah guna menghindari terjadinya kredit bermasalah.

\section{DAFTAR PUSTAKA}

Andriani, B., \& Susanto, R. (2019). Pengawasan Kredit PT. Bank Perkreditan Rakyat (BPR) Ophir Pasaman Barat. https://doi.org/10.31219/osf.io/aunvc

Alanshari, F., \& Marlius, D. (2018). Prosedur Pemberian Kredit KPR Pada PT. Bank Tabungan Negara (Persero) TBK Cabang Pembantu Bukittinggi. https://doi.org/10.31227/osf.io/rsfhc

Amelia, L., \& Marlius, D. (2018). Pengendalian Kredit Dalam Upaya Menciptakan Bank Yang Sehat Pada PT. Bank Pembangunan Daerah Sumatera Barat Cabang Utama Padang. https://doi.org/10.31227/osf.io/kpc64

Baiya, \& Fernos, J. (2019). Analisis Faktor-Faktor Penyebab Kredit Macet Pada Bank Nagari Cabang Siteba. https://doi.org/10.31227/osf.io/4xuks

Badrulzaman, Mariam Darus, Perjanjian Kredit Bank, Bandung:PT.Citra Aditya Bhakti,1991.

Darmawanto, \& Fernos, J. (2019). Prosedur Pemberian Kredit Pada Bank Nagari Cabang Sijunjung. https://doi.org/10.31227/osf.io/psqfy

Denico Doly Lumban Tobing, Penyelesaian Kredit Bermasalah Pada PT.Bank Danamon, Tbk. Cabang Semarang, Semarang: Universitas Diponegoro, 2009.

Ikbal, M., \& Marlius, D. (2017). Pengaruh Jumlah Taksiran Dan Uang Pinjaman Terhadap Laba Bersih Pada PT. Pegadaian (UPC) Gurun Laweh. https://doi.org/10.31227/osf.io/uch4a

Kasmir, Bank dan Lembaga Keuangan Lainya, PT Raja Grafindo Persada, Jakarta, 2011

Kasmir, Dasar-Dasar Perbankan, PT. Grafindo Persada, Jakarta, 2003 
Orlando, A., \& Susanto, R. (2019). Mekanisme Pencairan Kredit Usaha Rakyat Pada PT. Bank Rakyat Indonesia Unit Lubuk Buaya. https://doi.org/10.31219/osf.io/zuv2y

Rivai Veithzal dan Anria Permata Veithzal, Credit Management Handbook, PT Raja Grafindo Persada 2006

Shanjaya, A. R., \& Marlius, D. (2017). Peranan Laporan Keuangan Dalam Kebijaksanaan Pemberian Kredit Kepada Calon Nasabah Pada PT. BPR Batang Kapas. https://doi.org/10.31227/osf.io/uxmg6

Suhardjono, Kuncoro, Pengertian Kredit Bermasah, PT. Gramedia Pustaka Utama,Jakarta, 2002

Sutojo, Siswanto, Menangani Kredit Bermasalah, PT. Damar Mulia Pustaka, Jakarta, 2008

Suyatno, Thomas, Dasar-Dasar PerKreditan, PT Gramedia Pustaka Utama, Jakarta, 2003

Undang-Undang No. 10 tahun 1998 tentang perubahan atas undang-undang No. 7 tahun 1992

Undang-Undang RI No, 10 tahun 1998 Tentang Perbankan, Citra Umbara, Bandung, 2002 